\title{
グリセリンの最新研究開発動向と世界展望 \\ The Newest Research and Development Trend of Glycerin and its World Market Overview
}

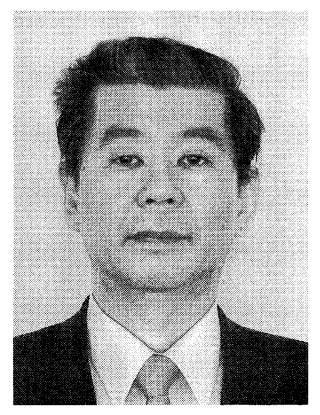

\author{
水島義和 \\ 株式会社オフィスワイズ \\ T164-0002 \\ 東京都中野区上高田 1-40-10
}

Yoshikazu MIZUSHIMA

Office Y's Co., Ltd.

1-40-10 Kamitakada Nakano-ku, Tokyo 164-0002,

JAPAN

論文要旨：グリセリンは古くからある物質でもあり，世界中で長年にわたって使用されてきた。しかし ながらバイオディーゼル燃料の世界的な普及により必然的に副産物として大量に産出され，価格低下，供 給過㮃を起こした。その結果として，グリセリンは新たな需要を生み出したかにみえたが，このバイオ燃 料の急速な普及，そして中国の急速な近代化に合わせて勃発した原料油脂の高騰，それに伴うグリセリン の一転した暴騰，など様相は複雑化してきている。ここではこの状況に焦点をあてて今後の展望について 論じてみたい。

Abstract: Glycerin is well known traditional chemical substance for long years, and consumed world widely. But this situation was changed by a rapid growth of biodiesel in the world and it caused price corruption and oversupply. As a result, it looks like glycerin could find a new application under this situation, but suddenly, glycerin lost these one because of skyrocketed feedstock market price due to a rapid growth of biodiesel and a big new purchase power by China. Now, market is very complicated, and I try to focus these situations and discuss glycerin future outlook.

Key words: glycerin, biodiesel, oversupply, new application, China, future outlook

\section{1 はじめに}

植物油脂，動物油脂などの高騰を受けて，あらゆる末 端製品が值上がりし，需要家はコスト維持にあえいでい る。同じくバイオディーゼル産業でも，使用される植物 油脂の原料価格が高騰したため, バイオデイーゼル燃料 製造時に副生するグリセリンの供給にも大きな変化をも たらした。バイオディーゼル産業に用いられている主要 植物油は大きく分けて三種類あるが，その価格は 2005 年半以降上昇を示しはじめた。 2006 年 10 月から 2007 年 10 月までの間, 米ドル換算でみると菜種油は $48 \%$, 大豆油は $66.6 \%$ ，パームオレインは $97.8 \%$ も昇してい $ろ^{1)}$ 。

植物油脂，動物油脂はなぜこのように高騰したのか？

連絡者：水島義和

E-mail : yoshikazu_mizushima@office-ys.biz
天候異変による収穫不振なのだろうか？ならば原料油脂 の販売価格は人件費，コストなどの単価に付加される生 産数量の割合が少なくなることになるので，やむなしと も思える。ところが，この間の平均収穫量にさほど大き な差はみられない。では, 残りの理由, 相場高騰という 名目で值上がりしているとしたならば，高騰の張本人は パーム，菜種，大豆などの栽培業者なのであろうか? は発想を変えて，この高騰の中で一番あえいでいるのは 誰か？それは油脂化学製品の製造業者である。オレオケ ミカル製品，バイオデイーゼル燃料など，石油製品との 価格競争という市場に置かれ，まったく元気がない。

脂肪アルコールは, 石油からの合成アルコール（もっ とも石油も高騰を続けてはいるものの植物油脂と比較す るとまだ上昇の割合は低い）との競争に太刀打ちでき ず，新規に稼働を開始するかまたは開始したメーカーは 意気消沈している。 
それでも彼らは工場を稼働させなければ利益は上がら ないので，生産を続けなければならない。脂肪酸業界も これを受けて価格上昇が続いており, 需要家もこの值上 げに対して大きな抵抗を示している。

さて，この中で特殊な状況に置かれているのがグリセ リンである。ここ数年はヨーロッパでの急速なバイオ ディーゼル燃料の普及により，副生するグリセリンはお 荷物としての扱いとなっていた。一時期は焼却するため の燃料代としての価值しかなく，バイオディーゼル生産 者からは金を出すから粗グリセリンを引き取って欲しい との話もあったほど。これを精製して純度の高いグリセ リンを製造してもまったく儲からない状況が長年続いて いた。過去数年を振り返ると純度の高いグリセリン価格 は 2004 年末の時点でかなり下落し，その状態を 2005 年， 2006 年と保っていた。この期間，グリセリンはミ ネラルウォーターよりも安值であった。それが今や，一 年前の価格の二倍以上である（Fig. 1）。

動植物油脂価格の高騰によって大きく振り回されてい るグリセリンであるが，本稿ではその最新研究開発動向 と世界市場について言及する。

\section{2 グリセリンの供給}

\section{$2 \cdot 1$ グリセリンは供給過剩か}

この原因はヨーロッパにおけるバイオディーゼル産業 の急速な伸びが原因であることが立証されている。政府 の助成金や低い原料価格がヨーロッパにおけるバイオ ディーゼル生産量を 2002 年の 1.06 百万 $\mathrm{t}$ から 2006 年の 4.32 百万 $\mathrm{t}$ に押し上げ，結果的にグリセリンの生産をこ の 4 年のうちにヨーロッパだけで約 32 万 $\mathrm{t}$ も増加させ たのである ${ }^{1)}$ 。当然グリセリン製品の低価格は，伝統的 な化粧品や食物，医療品における需要を促進しただけで はなく，ソルビトールやプロピレングリコールなどのそ の他のポリオールからグリセリンへの置き換えを促進し た。詳細は後の章で述べることとする。

このように安いグリセリンの大量の供給は，バイオ ディーゼルのブームによって保証され，それにより新し いグリセリンの活用法が生まれ，またはその主要な技術 はすでに存在していたため，コスト的に採算が合うと考 えられた訳である。これらのプロジェクトの背景は，必 然的に市場に現れた「何十万 $\mathrm{t} 」 も の$ 副生グリセリンの 「処分」に関して，EUでのバイオ燃料の $5.75 \%$ の混合を 2010 年までに義務化するとした EU の声明から，多くの 人が必然的に副生グリセリンは安定供給されると考えら れた結果である。

そしてアメリカの例でも明らかなように，多くの国で グリセリンに対する非常に急速な需要の増加が起きた。
その結果，いろいろなグリコールのグリセリンへの置き 換え，そしてグリセリンからのエピクロルヒドリンの生 産，などを背景として，今やキーとなるのは，グリセリ ン市場が 2006 年から 2007 年にかけて 30 万七へ拡大し た『中国』である。

\section{$2 \cdot 2$ グリセリンは供給不足か}

逆説的な質問への答えとなるが，このグリセリンの供 給市場状況が 2007 年初めから変わってきた。2006 年後 半まではグリセリンの需要は伸び続けたが, バイオ ディーゼル産業に用いられる原料価格の高騰がグリセリ ンの供給に変化をもたらした（Fig. 1)。

植物油の価格上昇の背景に関しては本稿では言及しな い。しかしながら「食べ物か燃料か」という議論は鋭い 焦点をあてている。この二者択一に直面し，食物業界 は，植物油に対して概して高值を支払っているといえ る。アフリカ, アジア, 南アメリカの多くの経済状況は 急速に成長している。人口についても同様である。彼ら の植物油脂の需要は飽くことを知らず, それらを手に入 れるためにこの対価を支払わざるを得ない状況を作り出 している。その結果, 植物油種と植物油の在庫は世界的 にもかなり薄くなり，たとえば菜種油はヨーロッパにお いてはいくつかの多国籍企業系搾油業者のバイオディー ゼル向けへの生産量を減らしたにもかかわらず，その入 手が困難となった。植物油市場専門家の意見が一致して いるのは, 在庫が補充され価格が「標準」に戻るには, 次の収穫サイクルが終わる（2009 年中ごろ）までかか るだろう，ということである。ヨーロッパのバイオ ディーゼル産業への影響は, 原料の菜種油の不足と菜種 メチルエステルの販売価格の $90 \%$ を原料が占める高值 であった。

植物油が高騰し始めたと同時に精製グリセリンも価格 上昇を始めた。2007 年初めには 650 米ドル程度だった

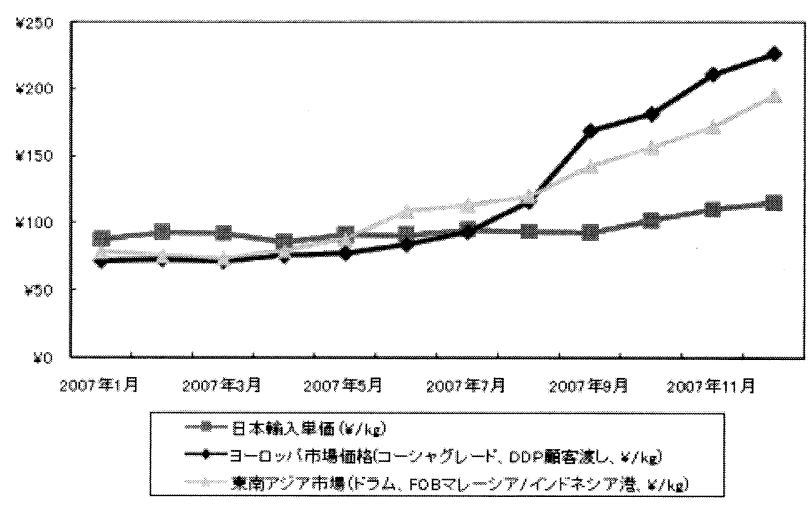

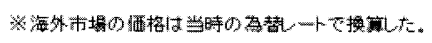

Fig. 1 精製グリセリン平均単価 ${ }^{3)}$ 
精製グリセリンが，今年初頭には一時 2,000 米ドルで売 りに出される状況になったのである。市場はこのような 二倍以上の価格を受け入れられるものなのであろうか? ヨーロッパのバイオディーゼル産業は, 原料となる菜 種価格の高騰により生産状態は足踏みを始め, 欧州バイ オディーゼル委員会（EBB）の統計によると 2006 年の 4.89 百万 $\mathrm{t}$ から 2007 年には 4.2 百万 $\mathrm{t}$ と 69 万 $\mathrm{t}$ も生産量 が落ち込んだ（Table 1)。これは 7 万 $\mathrm{t}$ 弱の副生グリセ リンの供給不足をもたらした。

さらに 2007 年の脂肪酸と脂肪アルコール製造からグ リセリン副産物の供給は，およそ $10 \%$ 落ち込み， 2006 年と比較しておよそ 1.5 万 $\mathrm{t}$ のグリセリンの不足に終 わっている。この結果, 運悪くも一昨年のグリセリン不 況の時代に，価格の安いグリセリンから代替品を作ろう といういくつかの大きなプロジェクトが立ち上がってい たのだが，その多くは市場を失くした。

\section{3 グリセリンの需要}

\section{$3 \cdot 1$ 伝統的なグリセリン使用法における需要}

グリセリン使用用途は広範囲に及んでおり，化粧品， 医薬品, 食料品, 夕バコ産業などで世界消費量の $60 \%$ を占めている。この既存分野での市場は欧米先進国では さほど拡大していない。ただし中国とインドは経済成長 が著しく, 雨国に加えて, ロシアが今後これらの用途で のグリセリン市場拡大のキーとなるであろう。

\section{$3 \cdot 2$ 中国需要の影響力}

2006 年の中国人 1 人当たりのグリセリン使用量は, ヨーロッパと比較して 10 分の 1 であった。しかしなが ら近年は，グリセリンの世界市場に対して中国が大きな 影響力を及ぼしている。2007 年，中国のグリセリン市 場は 2006 年の 2 倍以上の規模になり, 30 万 $\mathrm{t}$ に膨れ上 がったと推定されている。これは中国が精製グリセリン の最大の消費国（昨年度の米国の消費量より $44 \%$ も多 い）となったことを意味する゙)。しかしながら留意した いのは，この一年間で二倍の市場に膨れ上がっても，中 国のグリセリン使用量はまだ 1 人当たりヨーロッパの 5 分の 1 でしかないことである。

一方これに対応する供給をみれば，中国のグリセリン の精製能力は 2007 年に 27 万 $\mathrm{t}$ に拡大し, さらに建設中

Table 1 ヨーロッパのバイオディーゼル生産3)

(単位: 千 $\mathrm{t}$ )

\begin{tabular}{|l|r|r|r|r|r|r|}
\hline \multicolumn{1}{|r|}{ 年 } & 2002 & 2003 & 2004 & 2005 & 2006 & 2007 \\
\hline ヨーロッパ & 1065 & 1434 & 1933 & 3184 & 4890 & 4200 \\
\hline 内 & & & & & & \\
ドイツ & 450 & 715 & 1035 & 1669 & 2662 & 1500 \\
フランス & 366 & 357 & 348 & 492 & 743 & 1300 \\
\hline
\end{tabular}

の脂肪酸などの新規プラントからは 2008 年には少なく とも 4 万 $\mathrm{t}$ のグリセリンが供給可能となる。2007 年には 中国は自国でグリセリンを拈よそ9万生産している が, この量の 3 分の 2 は中国で急速に成長している脂肪 酸産業から来ているといわれている（アジアの財閥 Kuok や Kerry グループなどの合弁工場 $)^{2)}$ 。

その一方で気になる中国のバイオディーゼル産業につ いては，あちらこちらで噂に上ったものの, 実質的な生 産はわずかしかないといわれている。その原因はバイオ ディーゼルの原料が回収油であることが理由といわれて おり, 日本では揚げ物や, 天ぷら油など業務用料理油か らの回収油を一定量入手出来るのに対し, 中国の料理油 は揚げ物, 炒めもの，焼き物などに徹底的に繰り返し使 われるため, 回収出来た油は重合などで品質劣化したも のであり, その結果, 非常に劣った品質のバイオディー ゼルが製造されている。またその副生粗グリセリンも品 質が劣ったもの, と言われている。この理由から脂肪酸 産業からのグリセリン生産量が増加しても, 中国の消費 量増加に追いつかず，昨年は中国の精製グリセリン輸入 が㧍よそ 9 万 $\mathrm{t}$, 粗グリセリン輸入が拈よそ 12 万 $\mathrm{t}$ まで 拡大している。中国での精製グリセリンの供給事情は, 高品質の精製グリセリン（99.5\%）は主に輸入に頼り, 工業グレードの精製グリセリン（95\%）は主に国内で生 産されていた。

昨年度のこの輸入部分はほとんど独占的に東南アジア から来ていた。その理由は, 昨年まで ASEAN 地域から の輸入税は他の国と比較してかなり低かったからで, 本 年度は輸入税制が変わり各国の間で差がなくなった 東南アジアからの上質の精製グリセリンの大部分は 30\%の中国市場を形成している食品, 医薬そしてタバコ 用途で使われている。

輸入された精製グリセリンの価格はドラム詰 CIF（運 賃保険料达受渡し条件）中国主要港渡しで，2007 年初 めに $\mathrm{t}$ 当たり 600 米ドル以下だったのが, 2007 年末には $\mathrm{t}$ 当たり 1,800 米ドルを上回り, その後も急速に上昇し だ。

中国で 2007 年に需要が懪発的に伸びた原因はグリセ リンの新規用途開拓である。とくに，グリセリンからの エピクロロヒドリンの生産, 塗料製造におけるペンタエ リスリトールの代替, 不凍液および解凍用途におけるエ チレングリコールなどからの代替等で, これら合計で昨 年は約 10 万 $\mathrm{t}$ のグリセリン需要が中国に生まれたこと になる。

この用途に使用される工業用グレードの精製グリセリ ンは通常 95 98\%の濃度で販売されているが, その国 内価格は一年間で二倍近くまで上昇したので, 工場の採 
算も悪化していると思われる。それと同時に，製造原料 となる粗グリセリンの輸入価格も昨年初めの時点では 80\%濃度品で中国主要港渡しで $\mathrm{t}$ 当たり 150 米ドル前 後，ましてや中国産バイオディーゼル燃料副生の二級品 だと，無料ででも入手できていたのだが，昨年 12 月に は粗グリセリンも過去最高価格となり，80\%濃度品で $\mathrm{CIF}$ 中国主要港渡しで $\mathrm{t}$ 当たり 800 米ドル以上の価格で 取引された。

いずれにせよ 2007 年を通してみると，中国でグリセ リンの需要，価格および輸入のいずれもが爆発的に拡大 したが，さすがに中国のブローカーが暴走し過ぎて買い あさった反動も出てきており，市場でこの修正が始まっ ている。実際，2008 年初めより価格は低下し始めた。 これには，二つの理由がある。

先ず，米国およびブラジルから質の悪い粗グリセリン がオファーされ，バルク積み CIF 中国主要港渡し $\mathrm{t}$ 当た り 600 米ドルの安い価格で成約した。つまりわずか 1 力 月で価格が 4 分の 1 も下がったわけである。これらの契 約の多くは実際には履行されなかった模様だが，この価 格はすでに一人歩きを始めだ)。

一方，供給元の米国では粗グリセリンを処分する必要 があり，また，生産される製品の品質からしても，米国 のバイオディーゼル・メーカーは中国向けに中国の要求 する価格で販売するより他に方法がなかったことも原因 の一つである。

二番目の理由としては，本年初めに中国を襲った豪雪 のため中国の港湾施設が影響を受け，大量の輸入グリセ リンが港に止まった。その後天候は回復し一挙にこれら のグリセリンが市場に出回ったので，過剰供給の事態が 発生した。その結果，グリセリンの輸入は減少し，価格 も低下することになった。工業用精製グリセリンの中国 国内価格は 3 力月で $20 \%$ も低下し，現在の価格はドラム 詰め，指定先持ち込み渡し条件で $\mathrm{t}$ 当たり $\mathrm{RMB}$ （中国 元） 10,000 となっている。これに併せて中国向けの輸入 精製グリセリン価格も下落し始め，現在ドラム詰め， $\mathrm{CIF}$ 中国主要港渡し $\mathrm{t}$ 当たり 1,600 米ドルとなっている。

\section{4 グリセリンの用途開発}

\section{$4 \cdot 1$ 他のポリオールを代替した場合の需要の伸張}

消費増大の側面は代替である。精製グリセリンによる 代替の可能性として大きなものの一つはポリオールであ る。実際，精製グリセリンの価格次第で置き換えが可能 なものとしてソルビトール市場があり，この商品は年 120 万トンの取引が行われている。価格は純度 $70 \%$ 該当 品 570 ユーロで，グリセリンの価格次第で代替可能な範 囲にある。ソルビトールの $80 \%$ は練歯磨き産業に用い
られ，残りの大半は食品と化粧品に使用される。昨年は ヨーロッパのコルゲート(Colgate) 社が約 1 万 t の練歯 磨き用のソルビトールをグリセリンへ置き換えることを 立案し, その新規需要に対応するため, ユニリーバ社が 南アメリカで生産を行う計画があっだ)。

プロピレングリコールの市場は 140 万 $\mathrm{t}$ の規模で，価 格は $\mathrm{t}$ 当たり 1,000 ユーロを超えている。価格的には代 替市場として大変魅力的だが，残念ながらその内 80 万 $\mathrm{t}$ は不飽和ポリエステル繊維に使用されており，グリセリ ンによる代替は不可能である。残りの 60 万 $\mathrm{t}$ は, 強力 液体洗剂，ヘアケア，スキンケア，家畜飼料などに使用 される。グリセリンは家畜飼料産業で使われるプロピレ ングリコールの代替としては使用可能である。そしてま たインドや中国では塗料用でも消費され，南アフリカで は日焼け止めに使用する，といったものもある。

最後に，モノエチレングリコールは年 400 万 $\mathrm{t}$ の市場 があり，価格は t 当たり約 750 ユーロである。主なエチ レングリコールの用途はペットボトルである。その他の 潜在代替用途は防寒・防氷用で，道路や飛行場といった 場所での除氷製品や車向けフロントガラスのワイパーな どがある。中国やインドで塗料として使用されるペンタ エリスリトールのような他の高価なポリオールの精製グ リセリンによる代替研究は，すでに世界のあらゆる分野 で始まっている。グリセリンブローカーの HBI 社の予 測によると， 2010 年までには合計で 45 万 $\mathrm{t}$ の新規グリ セリン需要が起きるとしている ${ }^{6)}$ 。

\section{$4 \cdot 2$ グリセリン由来エピクロロヒドリン製造}

グリセリンの代替品が見つからなければ，グリセリン から新たな需要を作り出すことも可能であろう。そし て，これこそがグリセリンの新たな用途であり，第 3 の 需要として着目するものである。少々話を戻してみよ う。2006 年ヨーロッパのバイオディーゼル生産者は粗 グリセリンを回収し処分する購入者に対して料金を支 払っていた。精製グリセリンの品質は依然として低いレ ベルのままであった。多くの時間と資本を精製グリセリ ンの新たな用途を発見するために投資していた企業は， このような状況をチャンスと考えた。そしていろいろな プロジェクトが計画された。現在はグリセリンの主要な 新規用途はエピクロロヒドリン $(\mathrm{ECH})$ の生産であり, これから数年先もそうであり続けるであろう。何故なら 生産方法が比較的単純であり, ECH の值段も $\mathrm{t}$ 当たり 1,700 ユーロと高值だからである。この市場の規模は 120 万 $\mathrm{t}$ であり， $\mathrm{ECH}$ は主にエポキシ樹脂を生産するため に使用される。

このグリセリン法 $\mathrm{ECH}$ の原理についてはかねてより 知られていたものの, 大量生産に適さないとして工業化 
されていなかったが，ここ数年，ヨーロッパを中心とし たバイオディーゼル燃料の増産にともなうグリセリンの 大量副生，当時は市場価格も大幅に下落していたことか ら同法による量産技術の開発熱が一気に高まったのであ る。

この先陣を切ったのは世界的大化学企業のソルベイ (Sorvey) 社で, 2006 年フランスにて年 1 万 $\mathrm{t}$ の設備を 稼働させた。この原料となるグリセリンはフランスの半 国営ともいえるジエステル (Diester) 社の副生グリセリ ンを中心に供給されている模様である。続いて 2009 年 半ばの稼働をめどに，タイで 10 万 $\mathrm{t}$ の設備を建設する ことも明らかにしている。ここではマレーシア，インド ネシア，フィリピンからのグリセリン供給を予定してい るのであろう。ソルベイとスポルケミー(Spolchemie) 社 は稼働可能な工場を幾つかヨーロッパに所有しており， この 2 つ生産者は中国での生産に全力を注いでいる。 またソルベイの生産方法は完全に特許化されていると報 告されている。この生産技術は 2002 年にバルセロナで 開催された国際オレオケミカル会議にてある学者によっ て発表され，それに多くの化学会社が飛びついた してソルベイがこの特許を押さえた模様である。

もうひとつの注目すべきプロジェクトは世界最大手の ダウ (Dow) 社で, 中国で年 15 万tのプラントを 2009 年 から 2010 年をめどに操業させる計画を発表している。

従来はプロピレンを原料にしたアリルクロライド （ALC）法による製造が中心だったが，同法は得られる $\mathrm{ECH}$ に対し 50 倍もの大量の排水が発生することが課題 であった。ECH の需要が急増している中国では，不十 分な排水処理が引き起こす水質污染が社会問題化しつつ あり，昨年来，排水規制の強化から $\mathrm{ECH}$ 設備の稼働率 が低下し，需給がタイトになったことが報道されてい る。

こうしたなか，わが国でも鹿島ケミカルが，排水量を ALCの半分にでき，環境負荷の低減，石化原料への依 存度低下にもつながるとして，グリセリン法による量産 技術の開発を進めてきており，200t 規模の実証プラン トを 2008 年初夏には稼働をさせる予定である。

鹿島ケミカルは，旭硝子, ADEKA，三菱化学，三菱 商事が出資する企業で，主力の $\mathrm{ECH}$ の年 5 万 2 千 $\mathrm{t}$ の 生産設備を保有している，エポキシ樹脂原料向けを中心 に ECH は世界的に需要が拡大しており，安価なグリセ リンから ECH が製造できればビジネスチャンスは大き い。しかしながら各社ともプロジェクトの立案当初のグ リセリン価格が二ケ夕台であったこと，原料高騰による バイオディーゼル燃料生産の伸び悩みから，今や予想に 反してグリセリン価格は上昇基調にあることから，グリ
セリン法の事業性が疑問視され始めているのも事実であ る。このため鹿島ケミカルでは商業化に当たっては市場 環境をみて判断することとしている。ちなみに，ダイ ソーも 2008 年 3 月にも日産 $1 \mathrm{t}$ のパイロット設備を稼働 させると発表している。

\section{$4 \cdot 3$ グリセリンのその他の新規用途開発}

グリセリンによるプロピレングリコール生産計画は米 国の ADM 社, ダウ・ケミカル社, アシュランド (Ashland) 社そしてハンツマン (Huntsman) 社と提携したカー ギル (Cargill)社によって発表され, BASF 社やイネオス (INEOS) 社のような石油化学製品企業も新たに参入する のでは, との噂がある。しかしながら,この生産方法は 技術的には難しく多量のエネルギーを消費する。

他にも多くの製品がグリセリンの新規用途として考え られている。たとえば，グリセリン・カーボネイト (Glycerin Carbonate)である。コグニス (Cognis)社はハ ンッマン社のために特殊用途の溶剂を大量に生産すると 報じられており，フランスのノヴァンス (Novance) 社, イタリアのサルポリオリ (Farpolyoli)社などの幾つかの 企業も同様の事業を計画しているようである。だがその 市場はさほど大きくはない。

プロクター\&ギャンブル (Procter \& Gamble) 社によっ て特許化された Di-butoxyl（ジブトキシル）グリセリン とメチルターシャリルブチルエーテル (MTBE), エチル ターシャリルブチルエーテル (ETBE)の代替品と目され るグリセロールターシャルブチルエーテル (GTBE) は, ガソリン燃焼効率を高める効果が期待される。

ここで取り上げた大半の製品は合成繊維産業のアクロ レイン生産へのグリセリン使用についてである。フラン スの企業であるアルケマ(Arcema) 社が手をつけたと報 じられているように，このプロジェクトは始まっている ようである。他にも幾つかの計画が議論されている。

ここでは多数ある中の一つの計画を取り上げてみよ う。メタノー(Methanor) と呼ばれる会社が, アクゾ ノーベル (Akzo Nobel) 社と DSM 社のオランダにあるメ タノール工場を買い取り，どうやらそこで，グリセリン からメタノールを製造しようと計画しているようであ る。この会社はグリセリンをバイオメタノールに転換す る事業を開始するために, グリセリンの世界生産量の 80\%を購入しようとしている。バイオエタノールの現在 価格は $\mathrm{t}$ 当たり 250 ユーロ持込渡しなので, どのように して販売するつもりなのだろうか。

グリセリン新規用途の登場は需要に影響を与え始めた ばかりということであるがこの新たな用途の潜在性は大 きい。 


\section{5 おわりに}

今後の展望についてみると，バイオディーゼルには二 つの矛盾が同居している。東南アジアにおける多くのバ イオディーゼル生産業者, ブローカー達は非常に高価な 植物油価格のために，バイオディーゼルに対する需要や グリセリンの供給がさらに減少するだろうと考えてい る。

しかしながらヨーロッパでのバイオディーゼルへの政 府の支援は，政府からの指令書（Mandate）によって， ますます拡大されている。たとえば，2007 年から 2008 年の間フランスにおける指令書では，バイオ燃料の配合 要求は $3.5 \%$ から $5.75 \%$ まで増加し，ポーランドでは 0 から $3.5 \%$ まて増加した。英国における更なる指令書は 2008 年 5 月に適用され，同様にイタリアでもおそらく 2008 年の下半期までに適用されるであろう。この新た な，もしくは指令書配合増加要求割合の結果，ヨーロッ パで 2008 年には 2007 年と比べて合計 225 万 $\mathrm{t}$ 以上多い バイオディーゼルが消費されるであろうとの見積りもあ る。

この傾向は，さらに $5.75 \%$ から $6.25 \%$ に増加するフラ ンスの指令書や， 2009 年に 5,000 億ガロン（170 万 t) の使用を義務づけている米国の新しいエネルギー法案な どがあり，この流れは 2009 年中も続くであろう。

2008 年は，ヨーロッパのバイオディーゼル需要増加 分約半分は米国，アルゼンチン，インドネシアから供給 される見达みが強い。これは米国のエネルギー法案に よってバイオディーゼルと石油系ディーゼル燃料をブレ ンドして販売すると, $\mathrm{t}$ 当たり約 300 米ドルの助成金が 米国政府よりもらえることになるブレンダーズ・クレ ジット法 (Blenders Credit) があるためで，アルゼンチ ンやインドネシア産バイオディーゼルを米国でブレンド されてもこの助成金が適用されるからである2)。

しかしこの法案も 2008 年末には消滅するであろうと
Table 2 バイオディーゼルの世界生産予測 ${ }^{3)}$

(単位: 千 $\mathrm{t}$ )

\begin{tabular}{|c|c|c|c|c|}
\hline \multicolumn{2}{|r|}{ 年 } & 2007 & 2008 & 2009 \\
\hline \multicolumn{2}{|c|}{ ヨーロッパ } & 4200 & 5500 & 5800 \\
\hline \multirow[t]{2}{*}{ その内 } & ドイツ & 1500 & 1500 & 1500 \\
\hline & フランス & 1300 & 2450 & 2663 \\
\hline \multicolumn{2}{|c|}{ 世界の残り } & 2150 & 3030 & 4250 \\
\hline \multirow[t]{5}{*}{ その内 } & 米国 & 1500 & 1900 & 2000 \\
\hline & ブラジル & 30 & 100 & 100 \\
\hline & アルゼンチン & 150 & 400 & 1200 \\
\hline & 東南アジア & 400 & 300 & 800 \\
\hline & その他 & 70 & 30 & 100 \\
\hline \multicolumn{2}{|l|}{ 合計 } & 6350 & 8530 & 10000 \\
\hline \multicolumn{2}{|c|}{$\begin{array}{l}\text { バイオディーゼルから生成 } \\
\text { された粗グリセリン }\end{array}$} & 635 & 853 & 1000 \\
\hline
\end{tabular}

予測されているため，2009 年にはこの状況は変化する であろう。そして 2008 年に米国から輸出されるバイオ ディーゼルは, 価格が米国産よりももっと安いアルゼン チン，インドネシア産が大部分を占めるであろう。世界 的なバイオディーゼル生産の動向予測は Table 2 の通り である。

一方，その他の分野からのグリセリンは，鹸化からの グリセリン生産は減少するものの, 中国を中心とした脂 肪酸産業の拡大，そしてそれ以上に急速に合成アルコー ルの市場シェアを奪うことで脂肪アルコールが成長して いるので, オレオケミカル産業からのグリセリン生産は 増加するであろう。

それを踏まえると，世界規模のグリセリン生産は以下 の通りに成長しそうである（Table 3）。

しかしながら，現状でみればグリセリン市場は非常に 縮小しており，在庫水準は深刻な低さで不安定な状況に ある。世界はこの春までに一時的なグリセリン不足を経 験しているが，その一方でバイオディーゼル市場は一息 つき，そしてバイオ燃料製造は立ち直ろうとしている。

結論として 2008 年のグリセリン価格は, ヨーロッパ

Table 3 産業毎のグリセリンの生産 ${ }^{3)}$

\begin{tabular}{|c|c|c|c|c|c|}
\hline 年 & 2005 & 2006 & 2007 & 2008 & 2009 \\
\hline 畧化 & 160 & 150 & 155 & 130 & 110 \\
\hline 脂肪酸 & 410 & 450 & 470 & 470 & 490 \\
\hline バイオディーゼル & 368 & 609 & 635 & 853 & 1000 \\
\hline 脂肪アルコール & 130 & 160 & 180 & 190 & 200 \\
\hline 合成品 & 20 & - & - & - & - \\
\hline その他 & 35 & 30 & 30 & 30 & 30 \\
\hline 合計 & 1123 & 1399 & 1470 & 1673 & 1830 \\
\hline $\begin{array}{l}\text { グリセリン供給量の } \\
\text { 成長率 }\end{array}$ & - & $24.5 \%$ & $5.0 \%$ & $13.8 \%$ & $9.4 \%$ \\
\hline
\end{tabular}


政府のバイオディーゼル支援策によって生産が再開する のに伴い副生グリセリンの供給量が大幅に増え，価格は 下落するであろう。そして植物油は, 「食か燃料か」と 議論されている中で, 食用以外の販路がかなりのレベル に到達すると思われる。

この状況も，グリセリンをまったく生み出さない次世 代バイオディーゼル設備工場が出現する（ドイッで木く ずをガス化してディーゼル燃料を製造する実証プラント が立ち上がった）と，植物油からのバイオディーゼル生 産量は頭打ちになることが予測できる。
文献

1) オレオケミカル，3月号 (2008).

2) M. Heming, Oleoline Glycerine Quaterly Report (80) (2008).

3) M. Heming, Oleoline Glycerine Quaterly Report (79) (2007).

4) オレオケミカル, 5 月号 (2008).

5) オレオケミカル, 10 月号 (2007).

6) AOCS, AOMG 2002 World Oleochemical Conference Data. 